УДК 551.86:553.041:553.982.2

\title{
ПАЛЕОГЕОГРАФИЯ ТЮМЕНСКОЙ СВИТЫ В ПРЕДЕЛАХ УСТЬ-БАЛЫК-МАМОНТОВСКОГО ВАЛА
}

\author{
Староселец Дмитрий Андреевич', \\ d_star1997@mail.ru
}

\section{Смирнов Павел Витальевич 1 ,} geolog.08@mail.ru

\author{
1 Тюменский Государственный университет, \\ Россия, 625003, г. Тюмень, ул. Володарского, 6.
}

\begin{abstract}
Актуальность изучения тюменской свиты обоснована тем, что на настоящий момент наблюдается падение добычи нефти из нижнемеловых и верхнеюрских интервалов. Вследствие этого образуется необходимость в восполнении фонда добычи. Наибольшие перспективы осуществления дальнейшей добычи связывают с отложениями средней юры, представляющими долгосрочную перспективу на поиск, разведку и добычу уелеводородов в Западной Сибири. К тому же немаловажным фактором является распространение продуктивных отложений тюменской свиты в пределах территорий с развитой инфрраструктурой.

Цель: восстановить условия осадконакопления пластов ЮС 2 и ЮС з в пределах Усть-Балык-Мамонтовского вала.

Объекты: нефтеносные пласты ЮС 2 и ЮС з тюменской свиты на северо-западной части Усть-Бальк-Мамантовского вала.

Методы: литолого-фрациальный анализ кернового материала, включающий детальное описание керна, вьделение литогенетических типов пород, фаций и макрофраций, гранулометрический анализ, изучение петрографических особенностей пород; анализ геофизических данных, включая геофизические исследования скважин и сейсмические исследования.

Результаты. Изучены фациальные обстановки формирования пластов ЮС 2 и ЮС з тюменской свиты. Выявлено их латеральное и вертикальное распространение на исследуемом участке. Предложено разделение пласта ЮС2 на три пачки. Созданы четыре палеогеографические схемы пластов ЮС и ЮС з, из которых три относятся к пласту ЮС. Спрогнозированы зоны распространения пород-коллекторов с лучшими коллекторскими свойствами, и идентифицированы наиболее перспективные зоны для бурения. Сделаны выводы о валидности выявленных закономерностей для тюменской свиты в пределах близлежащих территорий.
\end{abstract}

\section{Ключевые слова:}

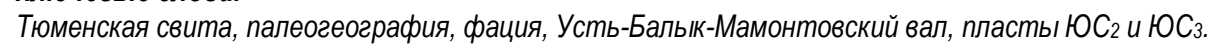

\section{Введение}

В настоящее время нефтегазовая промышленность Западной Сибири вступила в новый этап своего развития. Просматривается очевидная тенденция к снижению объёмов добычи нефти и газа, которая может быть преодолена вовлечением в промышленный оборот новых объектов минерально-сырьевой базы. Особое место при этом отводится юрским отложениям, в которых сосредоточено 29 \% от суммарных текущих извлекаемых запасов нефти в Западной Сибири.

В течение предшествующих этапов исследования геологии и нефтегазового потенциала ЗападноСибирской мегапровинции детальному изучению были подвергнуты нижнемеловые и верхнеюрские комплексы - ачимовский резервуар нижнего мела, баженовская, васюганская свиты верхней юры $[1,2]$. Однако длительная эксплуатация месторождений в указанных литостратиграфических комплексах предопределила истощение запасов углеводородов, а в случае с баженовской свитой, несмотря на колоссальный прогнозный потенциал, стоит засвидетельствовать, что эффективные методы ее эксплуатации в должной мере не разработаны. Все это актуализирует вопрос о включении в разработку новых объектов минерально-сырьевой базы традиционного типа.

Юрский литолого-стратиграфический комплекс не без оснований рассматривается как один из сложнейших по строению и наибольший по толщине нефтега- зоносный комплекс в Западной Сибири [3], с месторождениями этого комплекса связывают существенные перспективы дальнейшей нефтедобычи. По оценкам [3] в нижне-среднеюрском комплексе центральных и северных районов Западно-Сибирской провинции сосредоточено порядка 17,6 млрд т геологических запасов нефти. При этом в составе юрского комплекса резкой фациальной изменчивостью, литологической неоднородностью, фрагментарной или неполной изученностью характеризуются пласты $Ю_{2-9}$ [4] - то есть больший объем глинисто-песчаной толщи тюменской свиты нижней-средней юры (гор. $\left.Ю_{2}-Ю_{10}\right)$.

Тюменская свита континентального генезиса распространена регионально, в определенной мере спорадически, характеризуется различной толщиной, максимум которой фиксируется на юге и в центре НадымПур-Тазовского региона [3]. Значительный вклад во всестороннее изучение условий седиментации пород средней юры внесли А.Э. Конторович, Л.Г. Вакуленко, В.А. Казаненков и др. [5] и Л.Г. Вакуленко и П.А. Ян [6], основное внимание уделялось седиментогенезу коллекторов пласта $Ю_{2}$, и были сделаны выводы о возможных перспективах нефтеносности нижней и средней юры. А.Ю. Попов и В.А. Казаненков [7] установили закономерную смену обстановок осадконакопления и создали палеогеографические схемы на время формирования различных частей горизонта $\mathrm{Ю}_{2}$ в пределах северо-восточной части Широтного Приобья. 
Е.Н. Гавриловой в рамках последних исследований [8] сделаны выводы о неустойчивых в пространстве и времени субаэральных и мелководно-морских условиях седиментации тюменской свиты на Западе Широтного Приобья. Обоснование методики создания концептуальных геологических моделей тюменской свиты и подготовки на её основе моделей пластов $Ю_{2}$ выполнено в [9]. Томские геологи [10] изучили отпечатки растений, прирученные к тюменской и наунакской свитам на юго-востоке Западной Сибири, и ими же в соавторстве с В.В. Аносовым и В.П. Ивановым [11] на основе палеоботанических, литогеохимических и ИК-спектрометрических исследований выполнено стратиграфическое расчленение и корреляция отложений тюменской и наунакской свит. Особое внимание уделено анализу особенностей разработки и прогноза выработки запасов тюменской свиты на территории ХМАО-Югры [12].

Наряду с этим в тюменской свите достоверно установлено наличие высокоемких коллекторов [13], что создает предпосылки для дальнейшей успешной эксплуатации этого продуктивного горизонта. Из числа крупнейших месторождений, где основными продуктивными горизонтами является тюменская свита, нельзя не упомянуть Ем-Ёговское и Песчаное, относящиеся к Красноленинской группе месторождений. Восточнее описанной группы месторождений локализован Усть-Балык-Мамонтовский вал, являющийся составной частью более крупной структуры, в пределах которой также доказана нефтеносность тюменской свиты - Сургутского свода.

Как наглядно демонстрирует краткий анализ работ научных коллективов, особый интерес применительно к перспективам тюменской свиты проявляется к центральным и юго-восточным регионам ее распространения, что определяется перспективами наращивания ресурсной базы на уже хорошо обустроенных площадях с развитой инфраструктурой.

Несмотря на внушительный объем геологоразведочных работ, юрские горизонты нередко оказываются мало- или непродуктивными в пределах большинства разведочных площадей по причине низкого коллекторского потенциала песчано-алевролитовых пород. Ситуация усугубляется также отсутствием достоверных, хорошо аргументированных структурно-литологических и генетических моделей. Сложившаяся практика предопределила построение мелкомасштабных геологических моделей, которые зачастую малоинформативны для имеющих небольшие пространственные параметры, и резко дифференцированных залежей тюменской свиты - при таких масштабах моделирования они могут оказаться необнаруженными. Как справедливо отмечает Е.Н. Гаврилова, в связи с вертикальной и латеральной изменчивостью коллекторов тюменской свиты невозможно составить оптимальную сетку разведочного бурения без специальных подходов [13].

Описанные выше аспекты являются частными случаями общей проблемы несовершенства геологогенетических моделей тюменской свиты.

Целью настоящей статьи является реконструкция условий осадконакопления $\mathrm{FC}_{2}$ и $\mathrm{FC}_{3}$ в пределах
Усть-Балык-Мамонтовского вала. Разработанные модели призваны повысить эффективность прогнозирования распространения пород-коллекторов и изменчивости их ФЕС с возможной трансляцией полученных закономерностей на иные объекты нефтегазодобычи в пределах Сургутского свода.

\section{Материал и методы исследования}

Выделение тюменской свиты как самостоятельного объекта принято в 1956 г. на Всесоюзном совещании в г. Ленинграде. Стратотип тюменской свиты выделен в разрезе Тюменской опорной скважины. В её строении выделяется три подсвиты: нижняя $\left(\mathrm{J}_{2} \mathrm{a}-\mathrm{J}_{2} \mathrm{~b}\right.$, пласты $\left.Ю_{7}-Ю_{9}\right)$, средняя $\left(\mathrm{J}_{2} \mathrm{~b}\right.$, пласты $\left.Ю_{5}-Ю_{6}\right)$ и верхняя $\left(\mathrm{J}_{2} \mathrm{~b}-\mathrm{J}_{2} \mathrm{bt}\right.$, пласты $\left.\mathrm{Ю}_{2}-\mathrm{Ю}_{4}\right)$. Отложения представлены переслаиванием песчаников сероцветных, алевролитов и аргиллитов с редкими прослойками углей и конгломератов. Также для отложений тюменской свиты характерно обилие углистого детрита, отпечатков растений, остатков углефицированных корней, нередко отмечается присутствие погребенной почвы [4].

Участок исследования приурочен к Сургутскому нефтегазоносному району Среднеобской нефтегазоносной области, располагающейся в пределах центральной части Западно-Сибирской нефтегазоносной провинции.

В геологическом строении территории принимает участие комплекс пород мезозойско-кайнозойского возраста, несогласно залегающих на породах палеозойского возраста. В тектоническом плане участок исследований расположен в центральной части Западно-Сибирской плиты и находится в пределах Фроловского (Фроловская мегавпадина) и Среднеобского центрального (Сургутский свод) геоблоков. Он относится к переходу с востока на запад от УстьБалык-Мамонтовского вала (отрога Сургутского свода на его юго-западном погружении) в Тундринскую котловину (рис. 1), раскрывающуюся в северном направлении в пределах Фроловской мегавпадины. Склон Усть-Балык-Мамонтовского вала осложнен группой малоразмерных локальных поднятий.

Материалами для исследований послужили:

1. Керновые данные по вщсьми скважинам. Они включают в себя фотографии и описание керна, фотографии шлифов, результаты гранулометрических исследований, результаты макропалеонтологических и микрофаунистических анализов.

2. Данные каротажных диаграмм ГИС (более 50 скважин).

3. Данные сейсмических исследований в виде срезов сейсмического куба RGB-спектральной декомпозиции. Они использовались с целью нивелирования недостатка керновой информации и расширения фактологической базы. Всего на пласт $Ю_{3}$ проанализировано 12 срезов сейсмического куба. На пласт ЮC $_{2}$ создано 18 срезов. Спектральная декомпозиция даёт возможность наиболее детально выявить строение изучаемых интервалов, что особенно актуально в связи со сложнопостроенностью коллекторов тюменской свиты. 


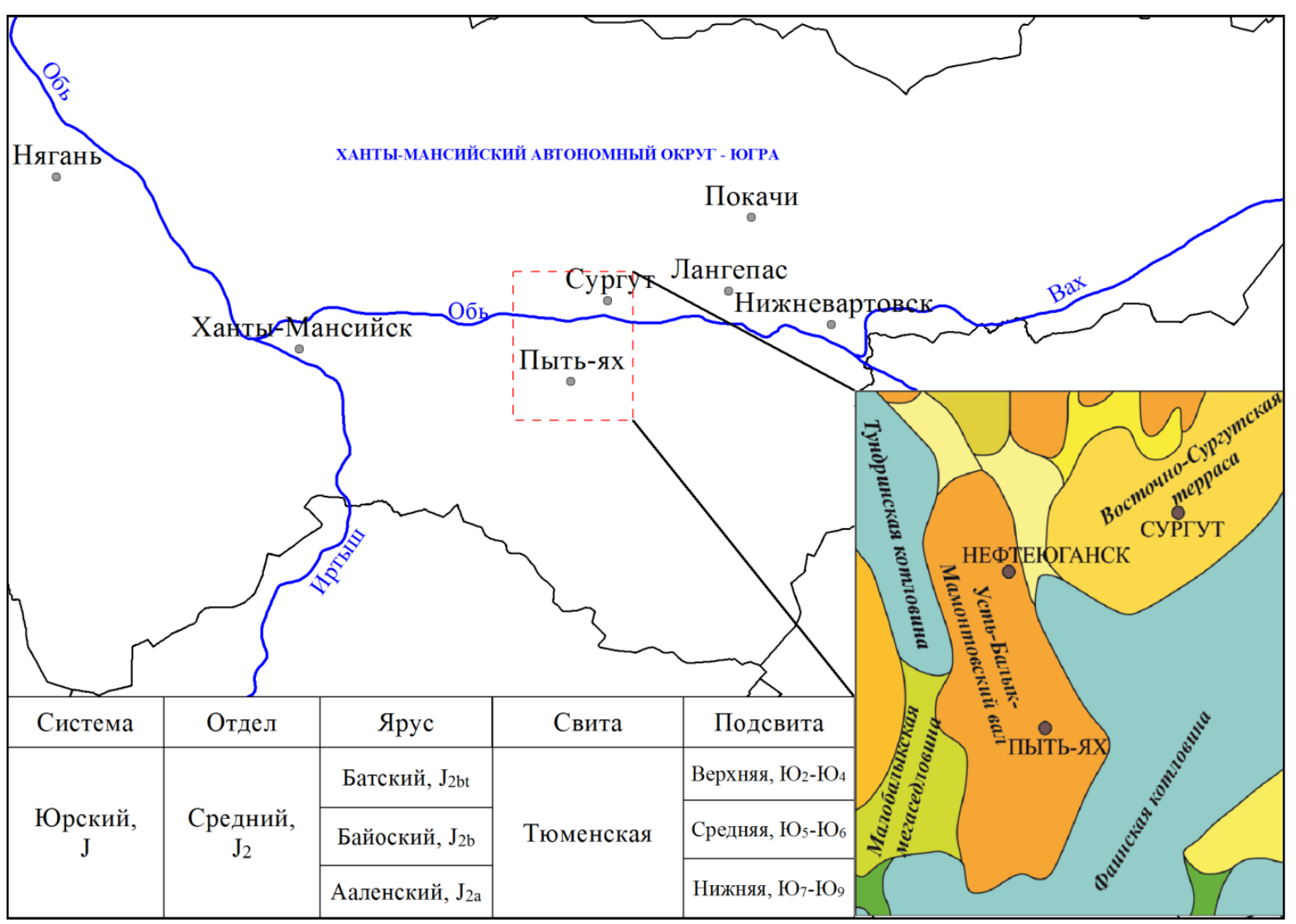

Pис. 1. Район исследований (фрагмент тектонической карты центральной части Западно-Сибирской плиты)

Fig. 1. Research district (fragment of the tectonic map of the central part of the West-Siberian plate)

Структурно-текстурные особенности, изученные по фотоматериалам керна, и общее макроскопическое описание пород послужили основой для уточнения обстановок осадконакопления на исследуемой территории.

Особое место отведено изучению текстур пород. Методической основной для характеристики данных параметров стали разработки и труды R.G. Walker, P.J. Noel [14], R.Ch. Selley [15].

Ихнофоссилии интерпретировались по методическим работам Дж. Памбертона [16, 17].

Проанализированные параметры экстраполированы на скважины, не имеющие кернового материала, с применением методики электрометрических моделей фаций В.С. Муромцева [18]. При анализе за основу приняты эталонные диаграммы, присущие каждой фации, взятые из методики В.С. Муромцева с адаптацией к особенностям гамма-каротажа. Анализ фаций выполнен в двух системах - пространственной (изучение закономерностей распределения фаций по площади для ограниченного стратиграфического интервала) и временной (изучение смены фаций по разрезу). Ведущий и резко преобладающий на фоне полидинамического ландшафта тип динамики среды принимался за основу классификации фаций [19].

Интерпретация срезов сейсмического куба проводилась при совместных сейсмофациальных исследованиях сейсмических разрезов по методике Р.Е. Шерифф, А.П. Грегори, П.Р. Вейл, Р.М. Митчем и др. [20].
Характеристика фациальных условий приведена в соответствии с классификацией О.С. Черновой [21]. Для интерпретации пространственных закономерностей формирования отложений меандровых систем, выявленных при изучении современных меандрирующих рек, использованы методические подходы зарубежных седиментологов $[22,23]$ и работы Д.А. Буша [24], который рассматривал изопахиты как топографическую карту русла.

Учтён опыт исследований последних лет в области моделирования речных систем, позволяющий наиболее точно спрогнозировать действие речных потоков в природе [25-28]. Прогнозирование основано на анализе изменения рельефа речного дна и образования русловых песчаных осадков (прирусловых баровых тел) при изменении скоростей водного потока. Вышеописанная практика показала свою эффективность при картировании палеорусел и смежных с ними объектов на срезах сейсмического куба RGB-спектральной декомпозиции.

\section{Результаты}

Пласт ЮС

В литологическом отношении породы пласта представлены переслаиванием алевролитов, аргиллитов и песчаников с подчиненными прослоями угля.

Песчаники светло-серые, от тонко- до мелкозернистых, с неравномерным распределением глинистого и карбонатного цемента; зернами сидерита; корешками растений; единичными интракластами аргиллита сидеритизированного (рис. 2). 

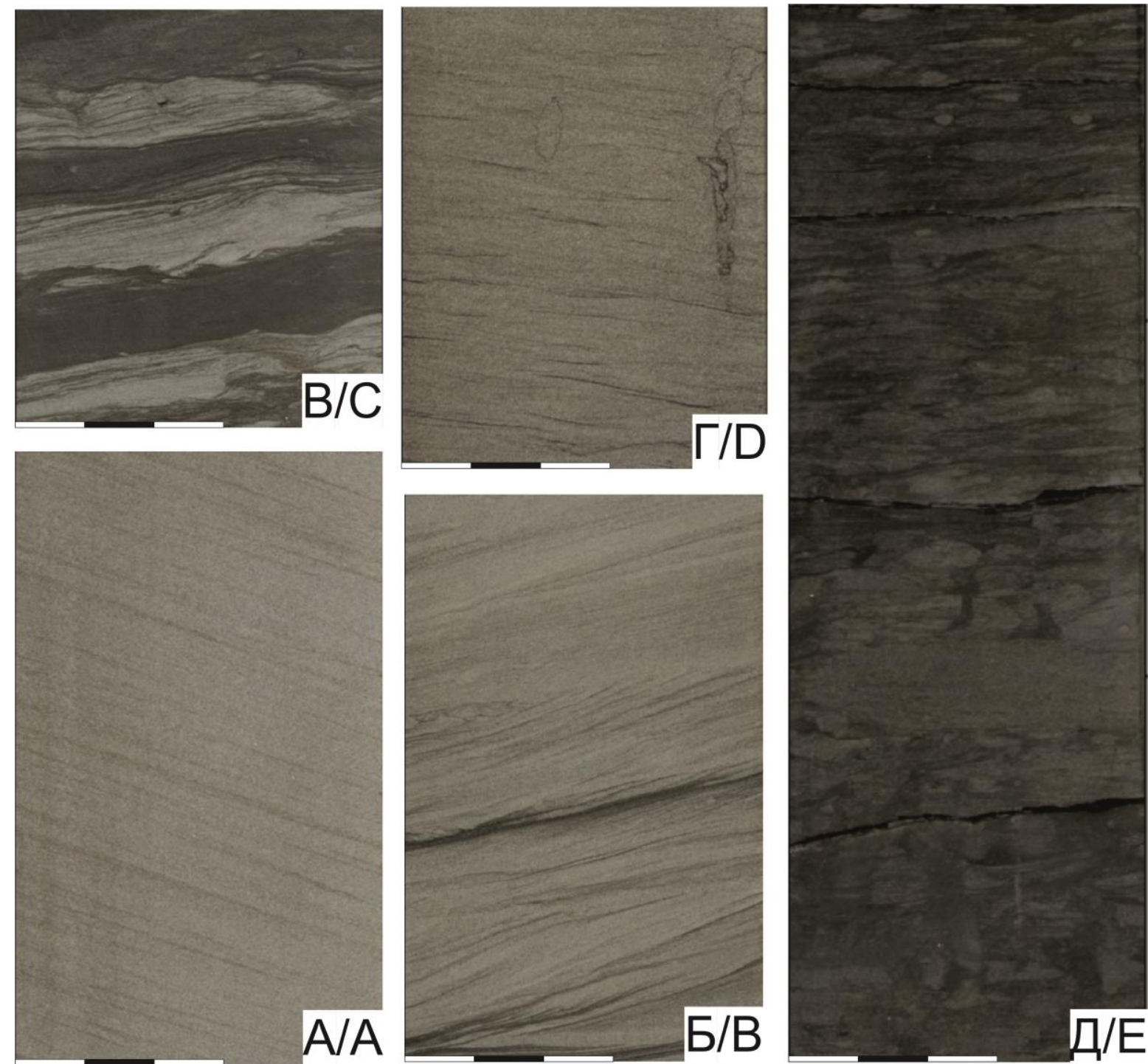

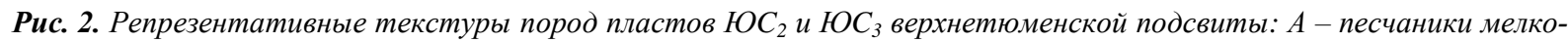
зернистые с намывами углистого детрита, подчёркивающего косую однонаправленную слоистость (субфация меандровой отмели; скважина 241 (глубина 3144,4 м)); Б- песчаники мелкозернистые с мелкомасштабной слоистостью с выраженными серийными швами, слоистость подчёркнута растительным детритом (субфация прируслового вала; скважсина 241 (глубина 3140,4 м)); В - алевролиты глинистые с волнистослоистой текстурой, переходящие в алевритистые глины, отмечается текстура деформачии (субфация песков разлива в пойме (кревассовые глифы); скважина 241 (глубина 3139,6 м)); Г - песчаники мелкосреднезернистые с прерывистой флазерной слоистостью подчёркнутой растительным детритом, $c$ биотурбациями типа: Skolithos (фация фронта дельты; скважина 241 (әлубина 3117,7 м)); Д - переслаивание алевритистых глин, алевролитов со следами сильной биотурбации, образующие линзовидную слоистость (фация продельты; скважина 241 (глубина 3108,6 м))

Fig. 2. Representative textures of rocks of $U S_{2}$ and $U S_{3}$ oil-bearing beds of the Upper Tyumen subdivision: A - sandstones are fine-grained with coal detritus inclusions emphasizing unidirectional layering (meander shoal subfaction; well 241 (depth 3144,4 m)); B - sandstones are fine-grained with small-scale layering with pronounced serial seams, layering is underlined by vegetative detritus (dorsal shaft subfaction; well 241 (depth 3140,4 $\mathrm{m}$ )); C - alevrolites are clayey with wavy layered texture passing into silvery clays, the texture of deformation is marked (subfraction of spill sands in the floodplain (Cruvass glyphs); well 241 (depth 3139,6 m)); D - sandstones are fine-medium grained with intermittent flaser layering underlined by vegetative detritus, with bioturbations of the type: Skolithos (delta front facies; well 241 (depth 3117,7 m)); E-alteration of silty clays, siltstones with traces of strong bioturbation, forming a lenticular layering (prodelta facies; well 241 (depth 3108,6 m))

Слоистость субгоризонтально-волнистая, пологоволнистая, субгоризонтальная, мелкая косая, пологонаклонная, участками прерывистая, подчеркнутая углисто-глинистым, глинистым и углистым, частично сидеритизированным материалом, реже наблюдается массивная текстура; местами текстура нарушена биотурбацией (ходы мелкие, округлые, овальные и субвертикальные короткие, выполненные алевритовым и песчаным материалами) и деформационными процессами. 
Алевролиты серые, светло- и темно-серые, разнозернистые, с неравномерным распределением глинистого и песчаного материалов; с корешками растений; зернами сидерита; с единичными трещинами синерезиса и закрытыми трещинами, замещёнными глинистым материалом; с редкими крупными углистыми остатками древесины.

Слоистость пологоволнистая, субгоризонтальная и линзовидная, подчеркнутая углистым, частично сидеритизированым и глинистым материалами, местами нарушенная биотурбацией (ходы мелкие, округлые, реже субгоризонтальные короткие, выполненные алевритовым материалом) и деформационными процессами.

Аргиллиты серые и темно-серые, от алевритистых до алевритовых; с зернами сидерита; с корешками растений и углистым растительным детритом.

Слоистость субгоризонтальная и линзовидная с прослоями и линзами алевритового материала, нарушенная биотурбацией (ходы мелкие, округлые, субвертикальные, выполненные алевритовым материалом) и деформационными процессами.

\section{Пласт ЮС 2}

В верхней части пласта породы представлены переслаиванием алевролитов и аргиллитов с подчиненными прослоями песчаников и единичными прослоями угля.

В основании пласт сложен песчаниками, с подчиненными прослоями аргиллитов, алевролитов и угля.

Песчаники светло-серые от тонко- до мелкозернистых, от алевритистых до алевритовых, с неравномерным распределением глинистого и карбонатного материалов; с углистым растительным детритом; с зернами сидерита; местами с интракластами аргиллита; с редкими корешками растений; с единичными закрытыми трещинами, залеченными кальцитом.

Слоистость преимущественно пологоволнистая и мелкая косая, участками прерывистая, реже субгоризонтальная и субгоризонтально-волнистая, подчеркнутая слойками углистого, частично сидеритизированного и глинистого материалов, местами нарушенная биотурбацией (Palaephycus и Planolites), изредка отмечается деформация осадка.

Алевролиты серые, светло- и темно-серые, разнозернистые, с неравномерным распределением глинистого и песчаного материалов, единичными прослоями известковистые; с зернами сидерита; с углистым растительным материалом и корешками растений; с единичными закрытыми трещинами, залеченными кальцитом.

Слоистость пологоволнистая, субгоризонтальная, субгоризонтально-волнистая, пологонаклонная срезанная и линзовидная, за счет слойков песчаного, глинистого и углистого, частично сидеритизированного материалов, нарушенная деформацией осадка и биотурбацией (ходы мелкие, округлые, выполнены алевритовым материалом). Биотурбационные текстуры представлены ходами: Chondrites, Planolites.

Аргиллиты серые и темно-серые, с неравномерным распределением алевритового материла; с ко- решками растений и углистыми растительными остатками; с зернами сидерита.

Слоистость тонкая субгоризонтально-линзовидная, субгоризонтальная и пологоволнистая, образованная слойками алевритового материала, местами нарушенная деформационными процессами и биотурбацией (Planolites).

По результатам гранулометрического анализа ситовым методом изученные породы представлены преимущественно алевритовыми песчаниками, в меньшей степени песчаниками, глинистыми и песчаными алевролитами.

Особенностью интервала разреза на уровне ОГ $\mathrm{Ю}_{3}$ и $\mathrm{Ю}_{2}$ является выделяемые на седиментационных срезах шнурки меандр, отождествляемые с палеоруслами. Все тела руслового генезиса построены с учётом уже имеющихся представлений о геоморфологии таких отложений [29, 30].

На наиболее репрезентативном срезе куба RGBспектральной декомпозиции (SHRP) на стратиграфическом уровне $\mathrm{Tю}_{2}+34$ мс (пласт $\mathrm{FC}_{3}$ ) показан пример выделения палеорусел пласта $Ю_{3}$ (рис. 3). На данном сейсмическом срезе выделены две палеореки с ответвлениями и притоками: южная и северная. Они просматриваются почти на всех срезах, созданных на пласт $\mathrm{FC}_{3}$.

\section{Обсуждение}

Обстановки формирования пластов ЮС и ЮС $_{3}$

Генерализованный сценарий формирования тюменской свиты сводится к обстановкам, при которых в областях выравнивания рельефа и заполнения отрицательных структур осадочным материалом в условиях континентального и переходного режима осадконакопления с многочисленными перерывами формировались песчано-алевритовые тела различной толщины [4].

Для ряда месторождений в пределах территории Усть-Балык-Мамонтовского свода генезис отложений получает различную интерпретацию. Коллектив ОАО «СИБНЕФТЕГЕОФИЗИКА» (Отчёт о результатах детальных сейсморазведочных работ... 2005-2006) связывает формирование обоих пластов как с дельтовыми, так и с аллювиальными процессами. А.Э. Конторович и др. [5] относят отложения пласта $Ю_{3}$ к аллювиальным, что справедливо и для пласта $\mathrm{Ю}_{2}$ за исключением его верхней части, которая связана с переходными условиями.

КолЛККТИв ОАО «СИБНЕФТЕГЕОФИЗИКА» В своих работах главным образом использовал методы ЗД сейсморазведки с применением кернового материала и данных ГИС. Коллектив ИНГГ СО РАН опирался на литологическое, палеонтолого-стратиграфическое, геохимическое изучение керна глубоких скважин, детальный сейсмостратиграфический анализ и учитывал более ранние исследования [5].

По результатам выполненного нами седиментологического анализа керновых данных выделены аллювиальная, болотная, озёрная и дельтовая обстановки осадконакопления. Определены следующие фации: равнинной реки с меандрирующим типом русла, включающей 
субфации меандровой отмели, прируслового вала, пойменных песков разлива, фации мелких проточных озёр и мелких застойных озёр, фацию торфяного болота, фации фронта дельты и продельты (таблица).

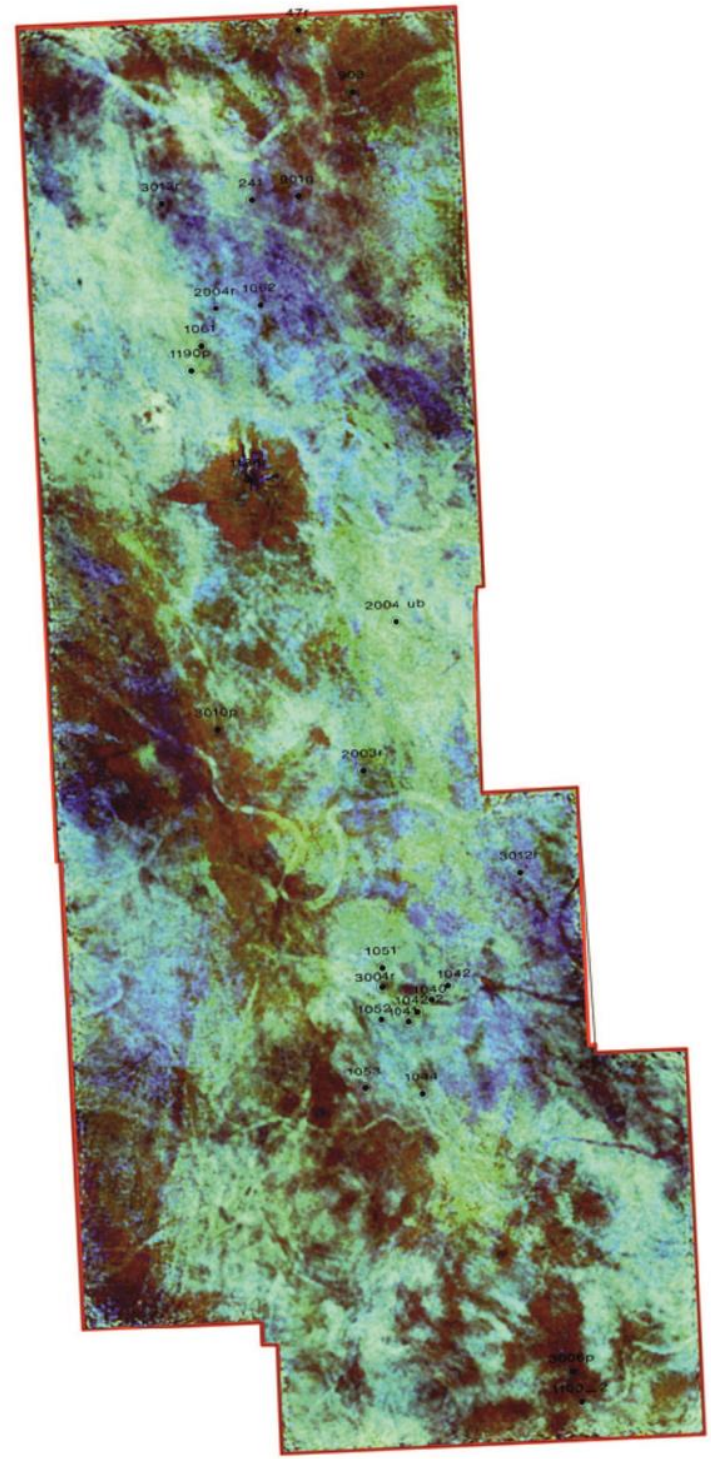

a/a

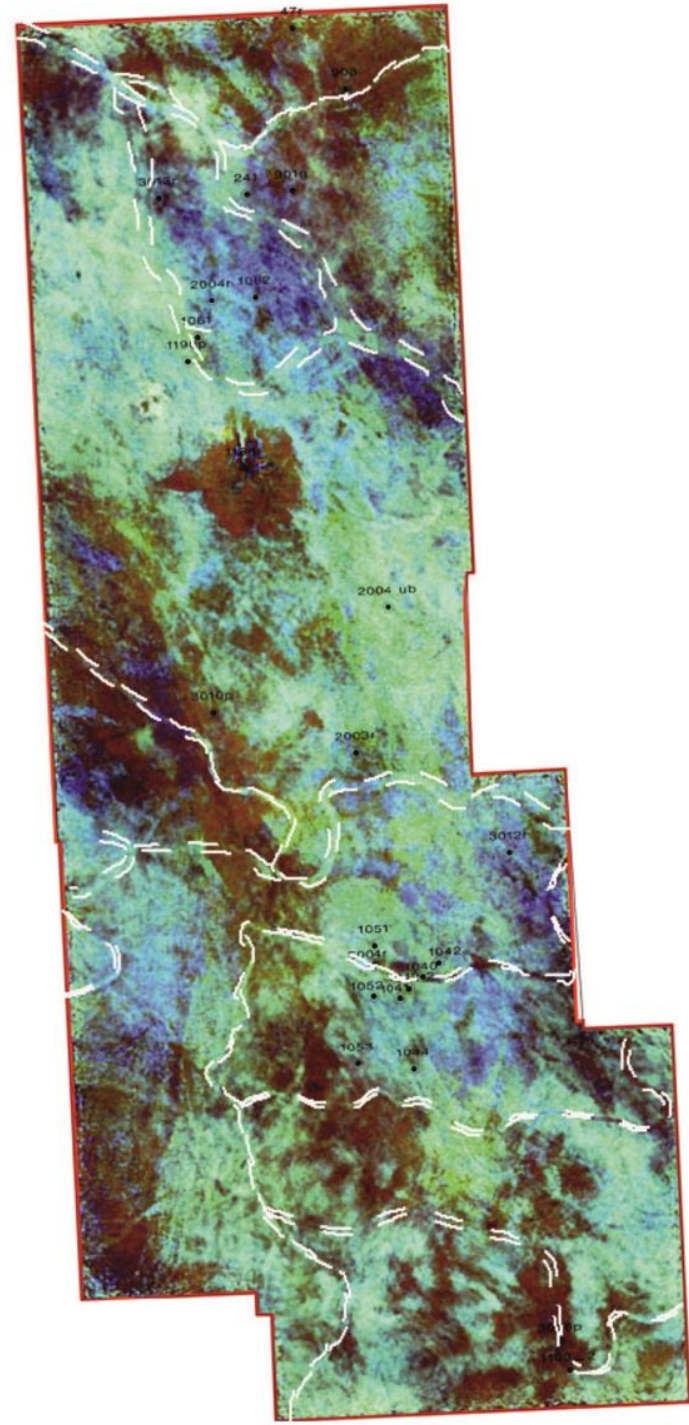

$6 / b$

Pис. 3. Сейсмические горизонтальный срез куба RGB-спектральной декомпозиции на стратиграфическом уровне пласта ЮС $:$ : а) срез пласта без выделенных объектов; б) срез пласта с выделением палеорусел

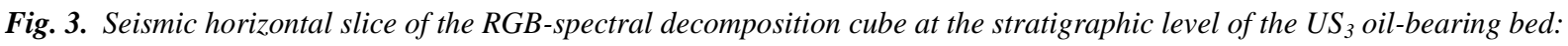
a) layer slice without selected objects; $b$ ) layer slice with the selection of paleochannels

Аллювиальная обстановка (макрофация) включает в себя отложения меандровой отмели, прируслового вала, пойменных песков разлива.

Песчаники средне-мелкозернистые с косой однонаправленной слоистостью, подчёркнутой растительным детритом толщиной в несколько метров интерпретированы авторами как отложения меандровых отмелей. Мелкозернистые песчаники, содержащие значительное количество углистого-глинистого материала с разнообразными слоистыми текстурами и серийными швами, обязаны своим формированием субфации прирусловых валов (береговых валов). Тонко-мелкозернистые песчаники с тонкими прослоями глинистых алевролитов с тонкой горизонтальной и волнистой слоистостью отнесены к пойменным пескам разлива (кревасовым глифам). Их присутствие отмечается в различных масштабах в большей части скважин.

Накопление наибольших по толщине песчаных тел и лучшие коллекторские свойства пластов $Ю_{2}$ и $\mathrm{OC}_{3}$ связаны с отложениями меандровых отмелей. $\mathrm{B}$ пласте $\mathrm{ЮC}_{3}$ в отложениях меандровых отмелей пористость варьируется от 12 до $15,1 \%$, а проницаемость - от 8 до 15 мД. Нефтенасыщенные коллектора пласта ЮС $_{2}$ в основном связаны с меандровыми отмелями с пористостью от 11,7 до $16 \%$ и проницаемостью от 7 до 16 мД. 
Таблица. Фациальная характеристика коллекторов пластов $Ю_{2}$ и $Ю_{3}$

Table. Facial characteristics of $U_{2}$ and $U S_{3}$ oil-bearing beds

\begin{tabular}{|c|c|c|c|}
\hline $\begin{array}{l}\text { Пласт (пачка) } \\
\text { Layer (packet) } \\
\end{array}$ & $\begin{array}{c}\text { Литологическая характеристика } \\
\text { Lithological characteristics } \\
\end{array}$ & $\begin{array}{c}\text { Характеристика ГИС } \\
\text { GIS characteristics }\end{array}$ & $\begin{array}{c}\text { Обстановка осадконакопления } \\
\text { Deposition environment }\end{array}$ \\
\hline $\begin{array}{l}\mathrm{OC}_{2} \text { (верхняя) } \\
\mathrm{US}_{2} \text { (upper) }\end{array}$ & $\begin{array}{l}\text { Песчаники тонкозернистые, пе- } \\
\text { реходящие в алевролиты и глины } \\
\text { Sandstones are fine-grained, turning } \\
\text { into siltstones and clays }\end{array}$ & & $\begin{array}{l}\text { Дельта речного влияния (фронт дельты, продель- } \\
\text { та) } \\
\text { River delta effect (delta front, prodelta) }\end{array}$ \\
\hline $\begin{array}{l}\mathrm{OC}_{2} \text { (средняя) } \\
\mathrm{US}_{2} \text { (middle) }\end{array}$ & $\begin{array}{l}\text { Песчаники мелкозернистые с } \\
\text { утонением зернистости вверх по } \\
\text { разрезу } \\
\text { Sandstones are fine-grained with a } \\
\text { tendency of fine grains upward the } \\
\text { section }\end{array}$ & & $\begin{array}{l}\text { Аллювиальная обстановка (равнинные меандри- } \\
\text { рующие реки, включая субфации: стрежневые } \\
\text { осадки русла, меандровые отмели, прирусловые } \\
\text { валы, пойменные болота, кревасовые глифы) } \\
\text { Alluvial environment (flat meandering rivers, includ- } \\
\text { ing subfacies: streambed sediments, meander shoals, } \\
\text { jetties, floodplains, crevass glyphs) }\end{array}$ \\
\hline $\begin{array}{l}\mathrm{FC}_{2} \text { (нижняя) } \\
\mathrm{US}_{2} \text { (lower) }\end{array}$ & $\begin{array}{l}\text { Песчаники мелкозернистые с } \\
\text { утонением зернистости вверх по } \\
\text { разрезу } \\
\text { Sandstones are fine-grained with a } \\
\text { fine grain thinning up the section }\end{array}$ & & $\begin{array}{l}\text { Аллювиальная обстановка (равнинные меандри- } \\
\text { рующие реки, включая субфации: стрежневые } \\
\text { осадки русла, меандровые отмели, прирусловые } \\
\text { валы, пойменные болота, кревасовые глифы) } \\
\text { Alluvial environment (flat meandering rivers, includ- } \\
\text { ing subfacies: streambed sediments, meander shoals, } \\
\text { jetties, floodplains, crevass glyphs) }\end{array}$ \\
\hline $\begin{array}{l}\mathrm{OC}_{3} \\
\mathrm{US}_{3}\end{array}$ & $\begin{array}{l}\text { Песчаники мелкозернистые с } \\
\text { утонением зернистости материа- } \\
\text { ла к кровле пласта } \\
\text { Sandstones are fine grained with } \\
\text { thinning the grain of the material to } \\
\text { the roof of the layer }\end{array}$ & & $\begin{array}{l}\text { Аллювиальная обстановка (равнинные меандри- } \\
\text { рующие реки, включая субфации: стрежневые } \\
\text { осадки русла, меандровые отмели, прирусловые } \\
\text { валы, пойменные болота, кревасовые глифы) } \\
\text { Alluvial environment (flat meandering rivers, includ- } \\
\text { ing subfacies: streambed sediments, meander shoals, } \\
\text { jetties, floodplains, crevass glyphs) }\end{array}$ \\
\hline
\end{tabular}

В скважине 3010Р присутствуют песчаники мелкотонкозернистые и алевролиты с неясной, пологоволнистой слоистостью, отмечаются включения мелких галек глинистых пород, слоистость часто подчёркнута растительным детритом, интерпретированы как озёра мелкие проточные. Выше по разрезу породы сложены алевролитами разнозернистыми и аргиллитами с горизонтальной слоистостью, характерно наличие углистого материала. Их формирование связано с переходом фациальных условий от озёр мелких проточных к озёрам застойным.

Породы, представленные углями, углистыми аргиллитами и аргиллитами с корнями углефицированных растений, нами идентифицированы как отложения, формировавшиеся в условиях торфяного болота

Дельтовая макрофация представлена отложениями фронта дельты и продельты.

Песчаники мелко-среднезернистые с косой, косоволнистой, прерывистой флазерной слоистостью, подчёркнутой растительным детритом, с биотурбациями типа Skolithos, интерпретированы как фация фронта дельтьл.
Алевритистые глины, переслаивающиеся с алевролитами, со следами активной биотурбации с нарушенной линзовидной и субгоризонтальной слоистостью интерпретированы как фация продельты.

\section{Интерпретация горизонтальных сейсмических срезов}

Общая сейсмическая картина для пласта $\mathrm{ЮC}_{3}$ на большей части территории является весьма хаотичной и в комплексе с керновыми данными интерпретирована как озёрно-аллювиальная обстановка.

Отложения пласта $\mathrm{FC}_{2}$ имеют более значительную толщину по сравнению с $Ю_{3}$ и представлены большим количеством фациальных обстановок, что осложняет его сейсмофациальную интерпретацию.

Глубокий анализ сейсмических срезов, построенных на различные временные интервалы, выявил резкое пространственное изменение положения палеорусел пласта $Ю_{2}$ на разные периоды его формирования. По скважинным данным (керн и ГИС) выделены три цикла седиментации отложений пласта. Комплексирование сейсмических и скважинных данных позволило разделить пласт на три пачки, связанные с раз- 
личным распределением геологических тел в пространстве, а также различной палеообстановкой формирования пласта.

Использование комплекса сейсмических срезов, созданных на определенную часть пласта, дало возможность проследить изменение сейсмической картины от его основания до завершения и определить развитие палеорусел во время формирования каждой из пачек.

Интерпретация сейсмических данных свидетельствует о субмеридиональной ориентировке русел.

В целях графического представления палеообстановок и геологической истории формирования пластов $Ю_{3}$ и $Ю_{2}$ создано четыре палеогеографические схемы, характеризующие отложения определен-

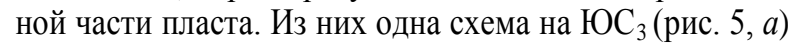
и три на $Ю_{2}$ (рис. 5, б-z).

Из проведённого анализа очевидно, что на формирование отложений пластов группы $\mathrm{FC}_{2}$ и $\mathrm{FC}_{3}$ наиболее существенную роль оказали эрозионноаккумуляционные процессы разноранговых аллювиальных систем, которые способствовали уникальному распределению индивидуальных аккумулятивных тел канального генезиса. Аллювиальные системы, существовавшие в различное время на разных участках территории, постоянно меандрировали, предопределив высокую неоднородность коллекторов как во времени, так и в пространстве. В конечный этап развития пласта $\mathrm{FC}_{2}$ формирование происходило в переходных условиях, связанных с фациями надводной дельтовой равнины, фронта дельты, продельты. На это указывает возрастание глинистых фракций в породе, начало преобладания текстур волнения и увеличивающейся степени биотурбированности отложений.

Дифференциация пласта $Ю_{2}$ на три пачки установлена в рамках предыдущих исследований [5]. На изучаемой нами территории выявлена такая же закономерность строения пласта $Ю_{2}$. Все вышеперечисленные пачки связаны с различными циклами существования палеорек и определенным комплексом фаций (рис. 4). Но подобная дифференциация на данный момент не учтена при проведении геологических работ на исследуемом участке. Поэтому, по предложению авторов, в будущем при корреляции разрезов скважин следует принимать во внимание трёхчленное строение отложений пласта для более точного представления о распространении и локализации коллекторов на данном участке. Это позволит дифференцировать залежи по уровню водонефтяного контакта в связи со способностью глинистых отложений в межпачечном пространстве выполнять роль флюидоупора. Как следствие, в дальнейшем такое деление может повысить точность гидродинамических моделей.

Во время формирования отложений нижней и средней пачки (рис. 5, б, в) на территории существовали озёрно-аллювиальные обстановки. Результаты позволяют идентифицировать, что за период накопления отложений нижней и средней пачки положение палеорек в пространстве многократно менялось. Происходило активное меандрирование, что предопределило формирование в вогнутой части русла песчаного аллювия. Лишь в период формирования третьей пачки фациальные условия претерпели серьезные изменения - это время ознаменовалось развитием региональной трансгрессии и, соответственно, переходных обстановок в северной части территории и формированием в центральной части дельтового комплекса фаций (рис. 5, г). Кратковременность существования указанных условий стала причиной накопления несущественного количества терригенного материала, явно недостаточного для формирования крупного резервуара для углеводородов. В конце периода форми-

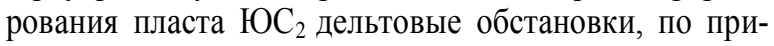
чине резкой трансгрессии, сменились морскими.

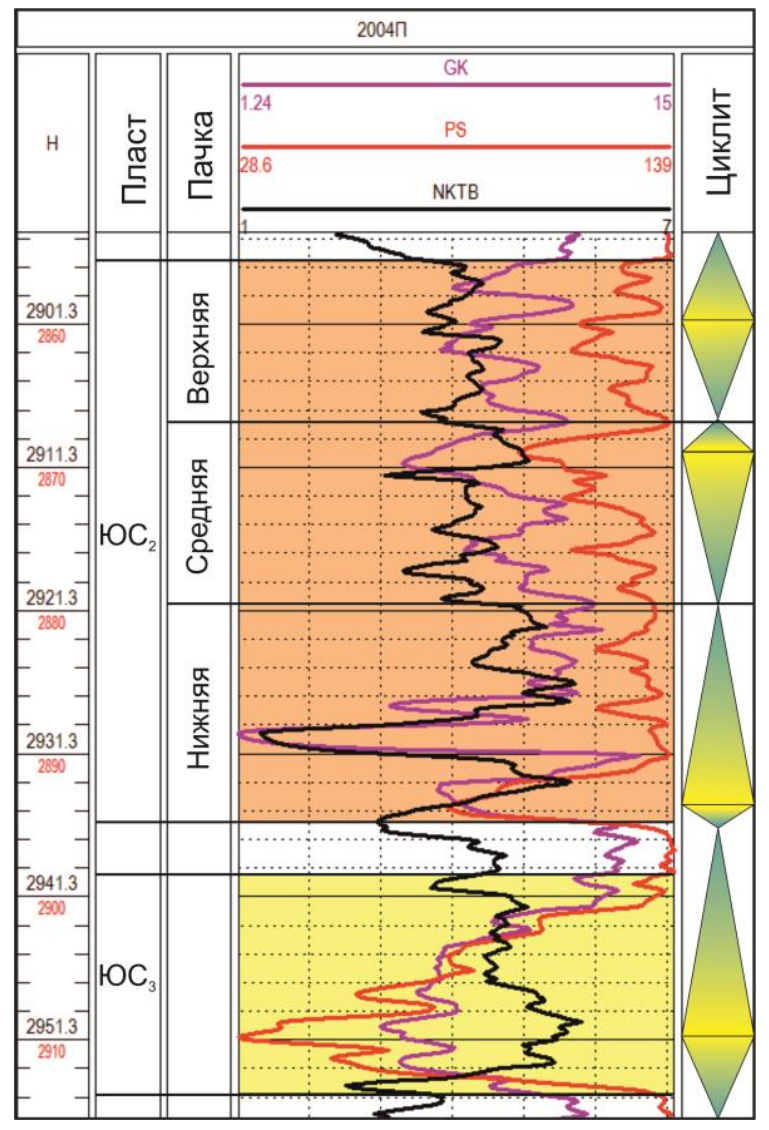

Рис. 4. Схема стратиграфического расчленения пластов $\mathrm{FC}_{2}$ и $\mathrm{FC}_{3}$ тюменской свить

Fig. 4. Scheme of stratigraphic separation of $U S_{2}$ and $U S_{3}$ oil-bearing beds of the Tyumen formation

На представленных палеогеографических схемах (рис. 5) идентифицированы наиболее перспективные зоны для бурения. По причине небольших пространственных параметров песчаных тел наибольший экономический эффект можно достигнуть при бурении в области, где возможно вскрыть несколько песчаных резервуаров. На представленных схемах эти области указаны как наиболее перспективные. К «перспективным» отнесены зоны, где продуктивность прогнозируется для отдельно локализованного песчаного тела. Также рекомендуется производить бурение горизонтальных скважин в зоне отложений меандровых отмелей, что призвано обеспечить вскрытие сразу несколько ловушек в латеральном направлении. 

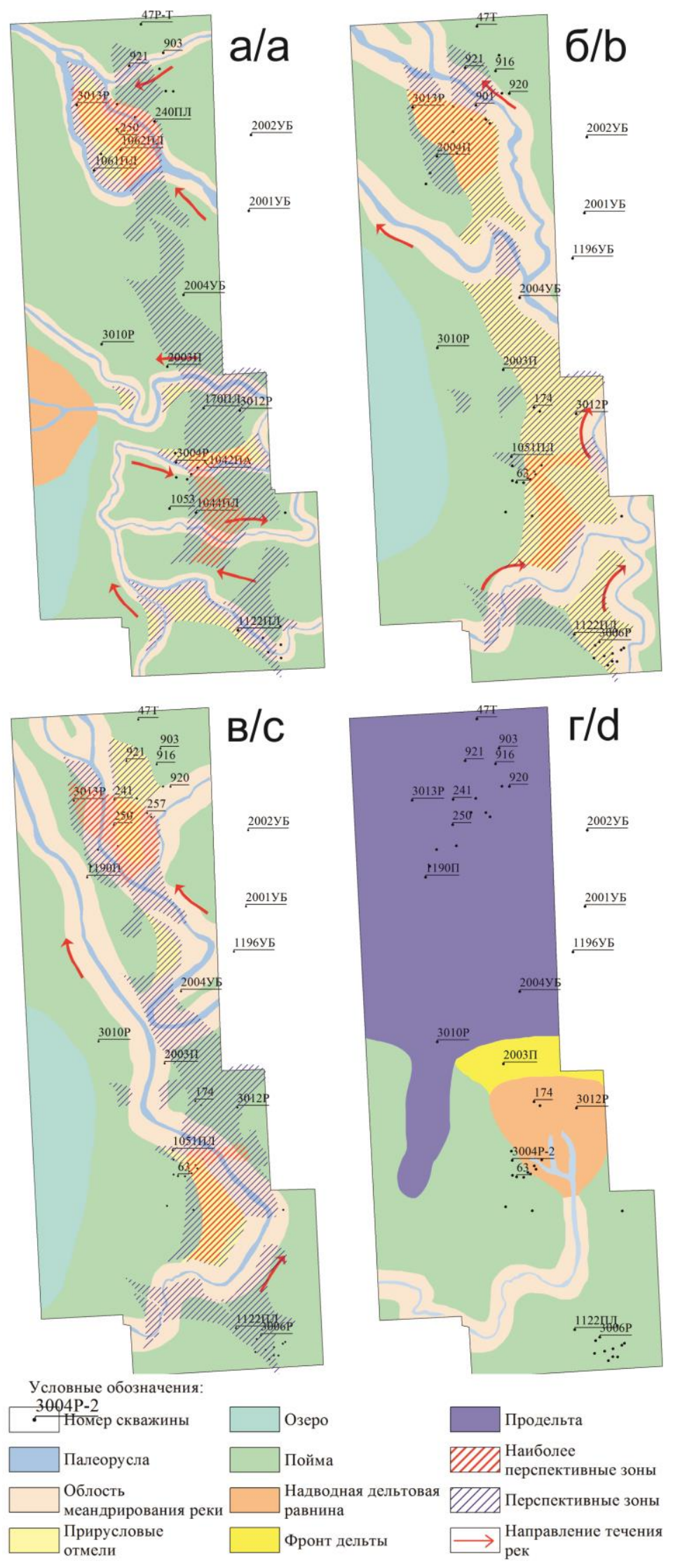

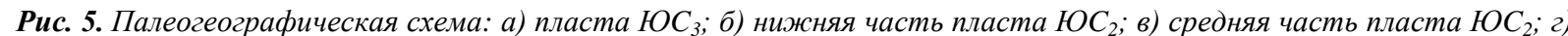
верхняя часть пласта $\mathrm{FC}_{2}$

Fig. 5. Paleogeographic scheme of: a) US $S_{3}$ oil-bearing bed; b) lower part of $U S_{2}$ oil-bearing bed; c) middle part of $U S_{2}$ oilbearing bed; d) upper part of $U S_{2}$ oil-bearing bed 
Нельзя не заметить, что опыт и результаты создания литолого-фациальных моделей в пределах УстьБалык-Мамонтовского вала могут оказаться востребованы для других нефтегазоносных объектов Сургутского свода на среднеюрском стратиграфическом уровне в связи с их формированием в схожих фациальных условиях.

Такие же закономерности формирования верхних отложений тюменской свиты выявлены для северной [31] и восточной [32] части Сургутского свода. А.Ю. Попов с соавторами для северо-востока Широтного Приобья установил, что нижняя часть отложений горизонта $Ю_{2}$ формировалась в условиях русловых и пойменных обстановок аллювиального комплекса, представленного трёхчленным строением седиментационных циклов. Вверх по разрезу происходит смена обстановок к дельтовым и прибрежноморским. Согласно данным В.А. Казаненкова и др. [31], изучавших обстановки формирования северовосточной части Хантейской гемиантиклизы, к началу формирования горизонта $\mathrm{Ю}_{2}$ в пределах вышеназванной структуры существовал континентальный режим осадконакопления, сменившийся к позднему бату на прибрежно-морской. Результаты выполненной фациальной интерпретации согласуются с выделенными другими исследователями [31, 32] обстановками в восточной и северной части Сургутского свода. Это позволяет предполагать, что установленные особенности в различных частях Сургутского свода $[31,32]$ характерны для большого числа перспективных объектов в его пределах. Дальнейшая интерполяция выявленных закономерностей вертикального и латерального распространения коллекторов и распределение их фильтрационных свойств в пределах Усть-Балык-Мамонтовского вала на территорию всего Сургутского свода позволит наиболее эффективно закладывать новые скважины и проводить корректную ресурсную оценку.

\section{Выводы}

1. На основании изучения керновых данных, материалов ГИС и сейсмических материалов детализировано строение пласта $\mathrm{FC}_{2}$ в западной части

\section{СПИСОК ЛИТЕРАТУРЬ}

1. Палеогеография Западно-Сибирского осадочного бассейна в юрском периоде / А.Э. Конторович, В.А. Конторович, С.В. Рыжкова, Б.Н. Шурыгин, Л.Г. Вакуленко, Е.А. Гайдебурова, В.П. Данилова, В.А. Казаненков, Н.С. Ким, Е.А. Костырева, В.И. Москвин, П.А. Ян // Геология и геофизика. 2013. - T. 54. - № 8. - C. 972-1012.

2. Палеогеография Западно-Сибирского осадочного бассейна в меловом периоде / А.Э. Конторович, С.В. Ершов, В.А. Казаненков, Ю.Н. Карогодин, В.А. Конторович, Н.К. Лебедева, Б.Л. Никитенко, Н.И. Попова, Б.Н. Шурыгин // Геология и геофизика. - 2014. - Т. 55. - № 5-6. - С. 745-776.

3. Скоробогатов В.А. Юрский продуктивный комплекс Западной Сибири: прошлое, настоящее, будущее // Вести газовой науки: науч.-техн. сб. Проблемы ресурсного обеспечения газодобывающих районов России. - 2017. - № 3 (31). - С. 36-58.

4. Перспективы разработки отложений тюменской свиты на территории ХМАО-Югры / А.А. Севастьянов, К.В. Коровин, О.П. Зотова, Д.И. Зубарев // Успехи современного естествознания. - 2016. - № 12-2. - С. 444-448.
Усть-Балык-Мамонтовского вала и предложена его дифференциация на три пачки.

2. При анализе кернового материала установлены условия седиментации пластов $\mathrm{OC}_{2}$ и $\mathrm{FC}_{3}$ тюменской свиты. Обстановка осадконакопления пласта $\mathrm{FC}_{3}$ интерпретирована как озёрноаллювиальная, связанная с равнинными меандрирующими реками и мелкими проточными и застойными озёрами. Палеообстановки формирования отложений нижней и средней пачек пласта $\mathrm{FC}_{2}$ также интерпретируются как озёрноаллювиальные, а отложения верхней пачки - как дельты речного влияния.

3. Разработаны палеогеографические схемы пластов $Ю_{2}$ и $Ю_{3}$ тюменской свиты, отражающие наиболее перспективные для разработки зоны. Предложенные схемы могут служить основой для дальнейшей разведки территории на перспективы нефти и газа, а также использоваться для моделирования кубов фаций, которые позволяют распределить коллекторские свойства в моделях.

4. Зоны с лучшими ФЕС $\left(\mathrm{ЮC}_{3}-\mathrm{K}_{\text {п }}\right.$ от 12 до $15,1 \%$, $\mathrm{K}_{\text {пр }}$ от 8 до 15 мД, ЮС $_{2}-\mathrm{K}_{\text {п }}$ от 11,8 до $16 \%$, $\mathrm{K}_{\text {пр }}$ от 7 до 16 мД) алеврито-песчаных разностей породколлекторов связаны с меандровыми отмелями.

5. Наиболее перспективные зоны для проведения буровых работ позволят вскрыть сразу несколько природных резервуаров руслового генезиса (меандровых отмелей), что позволяет рассматривать их в качестве наиболее перспективных и целесообразных к разработке.

6. Согласованность полученных авторами результатов фациальной интерпретации с выводами других исследователей об условиях осадконакопления тюменской свиты позволяет предполагать, что установленные особенности характерны для большого числа перспективных объектов в пределах Сургутского свода - выявленные закономерности являются валидными при дальнейшем геологическом моделировании и ресурсной оценке объектов тюменской свиты в пределах всего Сургутского свода.

5. Седиментогенез коллекторов среднего-верхнего бата и их нефтеносность в Широтном Приобье / А.Э. Конторович, Л.Г. Вакуленко, В.А. Казаненков, М.Б. Скворцов, П.А. Ян, В.В. Быков, А.Ю. Попов, Л.С. Саенко // Сибирское отделение РАН. Геология и Геофизика. - 2010. - № 2. - С. 187-200.

6. Вакуленко Л.Г., Ян П.А. Седиментогенез нефтеносного горизонта Ю2 и его значение при поисках и разведке залежей углеводородов // Известия Томского политехнического университета. - 2010. - Т. 316. - № 1. - С. 61-66.

7. Попов А.Ю., Казаненков В.А. Особенности батского седиментогенеза на северо-востоке Широтного Приобья // Известия Томского политехнического университета. - 2010. - Т. 316. № 1. - C. $67-71$

8. Гаврилова Е.Н. Формирование и нефтеносность высокоизменчивых среднеюрских природных резервуаров на Западе Широтного Приобья: автореф. дис. ... канд. геол.-минерал. наук. - М., 2011. -24 c.

9. Тюменская свита: методология создания концептуальных геологических моделей / М. Фёдорова, О. Кирзелёва, О. Катаев, Е. Ананьева, Ю. Осипова // Oil \& Gas Journal Russia. - 2016. № 11. - C. 60-63. 
10. Рычкова И.В., Шаминова М.И. Палеоботанические особенности тюменской и наунакской свит (средняя-верхняя юра юговостока Западной Сибири) // Известия Томского политехнического университета. - 2018. - Т. 329. - № 5. - С. 15-26.

11. Разработка комплексного подхода для стратиграфического расчленения и корреляции средне-верхнеюрских отложений юго-востока Западной Сибири / И.В. Рычкова, М.И. Шаминова, В.В. Аносов, В.П. Иванов // Стратиграфия. Геологическая корреляция. - 2019. - Т. 27. - № 3. - С. 24-39.

12. Особенности разработки отложений тюменской свиты О.П. Зотова, Д.И. Зубарев, К.В. Коровин, А.А. Севастьянов // Научный форум. Сибирь. - Тюмень: М-центр, 2018. - Т. 4. № 2. - С. 28-29.

13. Гаврилова Е.Н. Особенности геологического моделирования высокоизменчивых природных резервуаров тюменской свиты Западной Сибири // Технологии сейсморазведки. - 2009. № 1. - C. 91-99.

14. Walker R.G., Noel P.J. Facies models response to Sea level change. - GeoText 1, 1992. - 454 p.

15. Selley R.Ch. Applied sedimentology. - New York: Academic Press, 2000. -520 p.

16. Pemberton S.G., Frey R.W. Trace fossil nomenclature and the Planolites-Palaeophycus dilemma // Journal of Paleontology. 1982. - V. 56. - P. 843-881.

17. Pemberton S.G. Applications of ichnology to petroleum exploration: a core workshop. - SEPM Core Workshop No. 17, 1992. $429 \mathrm{p}$.

18. Муромцев В.С. Электрометрическая геология песчаных тел литологических ловушек нефти и газа. - М.: Недра, 1984. $260 \mathrm{c}$.

19. Ежова А.В., Тен Т.Г. Литология нефтегазоносных толщ. Томск: Изд-во ТПУ, 2013. - 122 с

20. Seismic stratigraphy - applications to hydrocarbon exploration / C.E. Payton, R. Sheriff, A.R. Gregory, P.R. Vail, R.M. Mitchum, S. Thompson, R.G. Todd, J.B. Sangree, J.M. Widmier, J.N. Bubb, W.G. Hatelid, L.F. Brown, W.L. Fisher, C.J. Stuart, C.A. Caughey, R.J. Weimer, T.L. Davis, M.T. Taner, R.E. Sheriff. - Tulsa, Oklahoma: American Association of Petroleum Geologists, 1977. $516 \mathrm{p}$.

21. Чернова О.С. Научные основы построения геостатических моделей и геометризации юрско-меловых природных резер- вуаров Западной Сибири на базе петрофизических и седиментологических исследований керна: дис. ... д-ра геол.-минерал. наук. - Томск, 2018. - 522 с

22. Reineck H.E., Singh I.B. Depositional sedimentary environments (with reference to terrigenous clastics). - Berlin; Heidelberg: Springer-Verlag, 1980. - $551 \mathrm{p}$

23. Reading H.G. Sedimentary environments and facies. - Blackwell, 1990. $-615 \mathrm{p}$

24. Busch D.A. Stratigraphic traps in sandstones: exploration techniques. - Tulsa, Oklahoma: American Association of Petroleum Geologists, 1974. - 174 p.

25. Yilmaz L. Applications in New River-meander Model // Journal of Geographical Research. - 2020. - V. 3. - P. 18-21. DOI: 10.30564/jgr.v3i1.1896

26. Yilmaz L. Development of River Meander Model // Journal of Geographical Research. - 2020. - V. 3. - P. 14-27. DOI: 10.30564/jgr.v3i1.1845

27. Yilmaz L. Empirical studies in alluvial streams // Journal of Geographical Research. - 2020. - V. 3. - P. 6-8. DOI: 10.30564/jgr.v3i1.1668

28. Yilmaz L. Discussion at maximum sediment discharge theory // Journal of Geographical Research. - 2020. - V. 3. - P. 1-5. DOI: 10.30564/jgr.v3i1.1572

29. Conybeare C.E.B. Geomorphology of oil and gas fields in sandstone bodies. - New York: Elsevier Scientific Publishing Company, 1976. - $341 \mathrm{p}$

30. Leeder M.R. Sedimentology. Process and product. - Netherlands: Springer, 1982. $-344 \mathrm{p}$.

31. Палеогеографические реконструкции для северо-восточной части Широтного Приобья на время формирования нефтегазоносного горизонта $Ю_{2}$ / А.Ю. Попов, Л.Г. Вакуленко, В.А. Казаненков, П.А. Ян // Геология и геофизика. - 2014. Т. 55. - № 5-6. - С. 777-786.

32. Обстановки формирования коллекторов горизонта $Ю_{2}$ в северо-восточной части Хантейской гемиантеклизы (Западная Сибирь) / В.А. Казаненков, А.Ю. Попов, Л.Г. Вакуленко, Л.С. Саенко, П.А. Ян // Геология нефти и газа. - 2009. - № 1. C. 46-53.

Поступила: 02.12.2021 2.

\section{Инорормация об авторах}

Староселец Д.А., аспирант, лаборант-исследователь лаборатории седиментологии и эволюции палеобиосферы Тюменского Государственного университета.

Смирнов П.В., кандидат геолого-минералогических наук, заведующий лабораторией седиментологии и эволюции палеобиосферы Тюменского Государственного университета. 
UDC 551.86:553.041:553.982.2

\title{
PALEOGEOGRAPHY OF THE TYUMEN FORMATION WITHIN THE UST-BALYK-MAMONTOV SHAFT
}

\author{
Dmitry A. Staroselets ${ }^{1}$, \\ d_star1997@mail.ru
}

\author{
Pavel V. Smirnov 1 , \\ geolog.08@mail.ru \\ 1 Tyumen State University, \\ 6 , Volodarsky street, Tyumen, 625003, Russia.
}

The relevance of studying the Tyumen formation is justified by the fact that at present there is a decline in oil production from the Lower Cretaceous and Upper Jurassic intervals. As a result, there is a need to replenish the production fund. The greatest prospects for further production are associated with Middle Jurassic deposits, which represent a long-term prospect for hydrocarbon prospecting, exploration and production in Western Siberia. In addition, an important factor is the spread of productive deposits of the Tyumen formation within the territories with developed infrastructure.

The main aim: to restore the conditions of sediment accumulation of US $S_{2}$ and US $S_{3}$ oil-bearing beds within the limits of Ust-Balik-Mamontov shaft.

Objects: oil-bearing beds of the US 2 and US 3 of the Tyumen formation in the northwestern part of the Ust-Balik-Mamantov shaft.

Methods: lithologic-facial analysis of core material, including detailed description of the core, identification of lithogenetic types of rocks, facies and macrofacies, particle size analysis, study of petrographic features of rocks; analysis of geophysical data, including well logging and seismic studies.

Results. The facial conditions of formation US 2 and US $S_{3}$ oil-bearing beds of the Tyumen formation were determined. Their lateral and vertical distribution in the investigated area was revealed. Separation of layers of US 2 into three packs was proposed. Four paleogeographical diagrams US 2 and US oil-bearing beds were created, three of them belong to US2 oil-bearing bed and show the paleogeographical arrangement for the time of formation of each of the packs. The zones of distribution of reservoir rocks with the best reservoir properties are predicted and the most promising zones for drilling are identified. The conclusions about validity of the revealed regularities for the Tyumen formation within the neighboring territories were made.

\section{Key words:}

Tyumen formation, palaeoenvironment, facies, Ust-Balyk-Mamontov shaft, US 2 and US 3 layers.

\section{REFERENCE}

1. Kontorovich A.E., Kontorovich V.A., Ryzhkova S.V., Shurygin B.N Vakulenko L.G., Gaideburova E.A., Danilova V.P., Kazanenkov V.A., Kim N.S., Kostyreva E.A., Moskvin V.I., Yan P.A. Jurassic paleogeography of the West Siberian sedimentary basin. Geology and geophysics, 2013, vol. 54, no. 8, pp. 972-1012. In Rus.

2. Kontorovich A.E., Ershov S.V., Kazanenkov V.A., Karogodin Y.N., Kontorovich V.A., Lebedeva N.K., Nikitenko B.L., Popova N.I., Shurygin B.N. Cretaceous paleogeography of the West Siberian sedimentary. Geology and geophysics, 2014, vol. 55, no. 5-6, pp. 972-1012. In Rus.

3. Skorobogatov V.A. Jurassic productive complex of Western Siberia: past, present, future. News of gas science: scientific and technical collection. Problems of resource supply in gas-producing regions of Russia, 2017, no. 3 (31), pp. 36-58. In Rus.

4. Sevastyanov A.A., Korovin K.V., Zotova O.P., Zubarev D.I. Prospects of development Tyumen suite deposits in the territory of KHMAO-Yugra. Successes of modern natural science, 2016, n. 12-2, pp. 444-448. In Rus.

5. Kontorovich A.E., Vakulenko L.G., Kazanenkov V.A., Yan P.A., Popov A.Yu., Saenko L.S., Skvortsov M.B., Bykov V.V. Sedimentogenesis and resource potential of middle-upper bathonian reservoirs in the Middle $\mathrm{Ob}^{\prime}$ region. Geology and Geophysics, 2010, vol. 51, no. 2, pp. 147-158. In Rus.

6. Vakulenko L.G., Yan P.A. Sedimentogenesis of the oil-bearing horizon $\mathrm{Yu}_{2}$ and its value at prospecting and exploration of hydrocarbon deposits. Bulletin of the Tomsk Polytechnic university, 2010, vol. 316, no. 1, pp. 61-66. In Rus.

7. Popov A.Yu., Kazanenkov V.A. Features of the Batsk sedimentogenesis in the north-east of the Shirotniy Priobye. Bulletin of the Tomsk Polytechnic university, 2010, vol. 316, no. 1, pp. 67-71. In Rus.

8. Gavrilova E.N Formirovanie i neftenosnost vysokoizmenchivykh sredneyurskikh prirodnykh rezervuarov na Zapade Shirotnogo
Priobya. Avtoreferat Diss. Kand. nauk [Formation and oil bearing capacity of the highly variable Middle-Jurassic natural reservoirs in the West of the Shirotniy Priobie region. Cand. Diss. Abstract]. Moscow, 2011. $24 \mathrm{p}$

9. Fodorova M., Kirzelova O., Katayev O., Ananyeva E., Osipova Yu. Tyumenskaya svita: metodologiya sozdaniya kontseptualnykh geologicheskikh modeley [Tyumen formation: methodology of conceptual geological models creation]. Oil \& Gas Journal Russia, 2016, no. 11, pp. 60-63

10. Rychkova I.V., Shaminova M.I. Paleobotanical features of Tyumen and naunak formations (middle-upper Jurassic of the southeast of West Siberia). Bulletin of the Tomsk Polytechnic University 2018, vol. 329, no. 5, pp. 15-26. In Rus.

11. Rychkova I.V., Shaminova M.I., Ivanov V.P., Anosov V.V. Development of the integrated approach to stratigraphic subdivision and correlation of middle-upper Jurassic deposits in southeastern West Siberia. Stratigraphy and Geological Correlation, 2019, vol. 27, no. 3, pp. 297-310. In Rus.

12. Zotova O.P., Zubarev D.I., Korovin K.V., Sevastianov A.A. Features of the development of deposits Tyumen suite. Scientific forum. Siberia. Tyumen, M-Center Publ., 2018. Vol. 4, no. 2, pp. 28-29. In Rus.

13. Gavrilova E.N. Osobennosti geologicheskogo modelirovaniya vysokoizmenchivykh prirodnykh rezervuarov tyumenskoy svity Zapadnoy Sibiri [Features of geological modeling of highly variable natural reservoirs of the Tyumen Formation in Western Siberia]. Tekhnologii seysmorazvedki, 2009, no. 2, pp. 104-108.

14. Walker R.G., Noel P.J. Facies models response to Sea level change. GeoText 1, 1992. $454 \mathrm{p}$.

15. Selley R.Ch. Applied Sedimentology. New York, Academic Press Publ., 2000. $520 \mathrm{p}$

16. Pemberton S.G., Frey R.W. Trace fossil nomenclature and the Planolites-Palaeophycus dilemma. Journal of Paleontology, 1982, vol. 10, pp. 843-881. 
17. Pemberton S.G. Applications of ichnology to petroleum exploration: a core workshop. SEPM Core Workshop no. 17, 1992. 429 p.

18. Muromtsev V.S. Elektrometricheskaya geologiya peschanykh tel litologicheskikh lovushek nefti $i$ gaza [Electrometric geology of sandbodies - lithological traps of oil and gas]. Moscow, Nedra Publ., 1984. $260 \mathrm{p}$.

19. Ezhova A.V., Ten T.G. Litologiya neftegazonosnykh tolshch [Lithology of oil and gas bearing thicknesses]. Tomsk, TPU Publ., 2013. 122 p.

20. Payton C.E., Sheriff R., Gregory A.R., Vail P.R., Mitchum R.M., Thompson S., Todd R.G., Sangree J.B., Widmier J.M., Bubb J.N. Hatelid W.G., Brown L.F., Fisher W.L., Stuart C.J., Caughey C.A., Weimer R.J., Davis T.L., Taner M.T., Sheriff R.E. Seismic Stratigraphy - applications to hydrocarbon exploration. Tulsa, Oklahoma, American Association of Petroleum Geologists, 1977. $516 \mathrm{p}$.

21. Chernova O.S. Nauchnye osnovy postroeniya geostaticheskikh modeley i geometrizatsii yursko-melovykh prirodnykh rezervuarov Zapadnoy Sibiri na baze petrofizicheskikh $i$ sedimentologicheskikh issledovaniy kerna. Diss. Dokt. nauk [Scientific bases of construction of geostatic models and geometry of Jurassic-Cretaceous natural reservoirs of Western Siberia on the basis of petrophysical and sedimentological researches of core Dr. Diss.]. Tomsk, 2018 $522 \mathrm{p}$.

22. Reineck H.E., Singh I.B. Depositional sedimentary environments (With Reference to Terrigenous Clastics). Berlin, Heidelberg, Springer-Verlag, $1980.551 \mathrm{p}$

23. Reading H.G. Sedimentary environments and facies. Blackwell, 1990. 615 p.

24. Busch D.A. Stratigraphic traps in sandstones: exploration techniques. Tulsa, Oklahoma, American Association of Petroleum Geologists, 1974. $174 \mathrm{p}$.
25. Yilmaz L. Applications in New River-meander Model. Journal of Geographical Research, 2020, vol. 3, pp. 18-21. DOI: 10.30564/jgr.v3i1.1896

26. Yilmaz L. Development of River Meander Model. Journal of Geographical Research, 2020, vol. 3, pp. 14-27. DOI: 10.30564/jgr.v3i1.1845

27. Yilmaz L. Empirical studies in alluvial streams. Journal of Geographical Research, 2020, vol. 3, pp. 6-8. DOI: 10.30564/jgr.v3i1.1668

28. Yilmaz L. Discussion at maximum sediment discharge theory. Journal of Geographical Research, 2020, vol. 3, pp. 1-5. DOI: 10.30564/jgr.v3i1.1572

29. Conybeare C.E.B. Geomorphology of oil and gas fields in sandstone bodies. New York, Elsevier Scientific Publ. Company, 1976. $341 \mathrm{p}$.

30. Leeder M.R. Sedimentology. Process and product. Netherlands, Springer, $1982.344 \mathrm{p}$.

31. Popov A., Vakulenko L.G., Kazanenkov V.A., Yan P.A. Paleogeographical reconstructions for the northeastern part of the Latitudinal $\mathrm{Ob}^{\prime}$ region during the formation of petroleum horizon $\mathrm{J} 2$. Geology and geophysics, 2014, vol. 55, no. 5-6, pp. 777-786. In Rus.

32. Kasanenkov V.A., Popov A.Yu., Vakulenko L.G., Sayenko L.S., Yan P.A. Environments of reservoir formation of $\mathrm{YU}_{2}$ horizon in the north-eastern part of Khantei hemianteclise (West Siberia). Oil and gas geology, 2009, no. 1, pp. 46-53. In Rus.

Received: 2 December 2021.

\section{Information about the authors}

Dmitry A. Staroselets, postgraduate student, laboratory researcher, Tyumen State University.

Pavel V. Smirnov, Cand. Sc., head of the Laboratory of Sedimentology and Paleobiosphere Evolution, Tyumen State University. 